\title{
光源制御をマイタケの生体電位の自発性リズム変動に連動させた茸栽培の試み
}

\author{
平間淳司 ${ }^{1} \cdot$ 松岡大輔 ${ }^{2} \cdot$ 松井良雄 ${ }^{3} \cdot$ 西堀耕三 ${ }^{4}$ \\ ${ }^{1}$ 金沢工業大学工学部 光電磁場科学応用研究所 921-8501 石川県石川郡野々市町扇が丘 7-1 \\ ${ }^{2}$ 株式会社シーテック 467-8520 愛知県名古屋市瑞穂区洲雲町 4-45 \\ ${ }^{3}$ 金沢学院短期大学 食物栄養学科 $920-1392$ 金沢市末町 10 \\ ${ }^{4}(\mathrm{KK})$ 雪国まいたけ 949-6695 新潟県南魚沼市余川 89
}

\section{Mushroom Farming using Illumination Control by Synchronization with the Spontaneous Rhythm of the Bio-electric Potential of Grifola frondosa (Maitake Mushroom)}

\author{
Junji HIRAMA $^{1}$, Daisuke MATSUOKA ${ }^{2}$, Yoshio MATSUI ${ }^{3}$ and Kouzou NiSHiBORI ${ }^{4}$ \\ ${ }^{1}$ Kanazawa Institute of Techonology, Adobanced Optical Electro Magnetic Field Science Lobolatory, \\ 7-1, Ohgigaoka, Nonoichimachi, Ishikawa, 921-8501, Japan \\ ${ }^{2}$ C-TECH Co., Ltd., 4-45, Sugumo-cyo, Mizuhoku, Aichi, 467-8520, Japan \\ ${ }^{3}$ Department of Food \& Nutrition, Kanazawa Gakuin College, \\ Sue-machi 10, Kanazawa, Ishikawa, 920-1392, Japan \\ ${ }^{4}$ Yukiguni Maitake Co., Ltd., 89, Yokawa, Minamiuonumashi, Niigata, 949-6695, Japan
}

\begin{abstract}
In our previous study of responses of bio-electric potential of the Grifola frondosa fruit body, it was revealed that the bio-electric potential changed according to different light stimuli and the farming environment. Furthermore, it was shown that the changes accompanied a spontaneous, semi-cyclic, biorhythm. Based on these results, in this study, we suggest a new farming technique (using a fruit body as a biosensor) that uses light stimuli, synchronized with the spontaneous rhythm of the bio-electric potential. The illumination (light-dark time) was experimentally controlled in accordance with the fluctuation of bio-electric potential over a period of one hour. Results indicated that good morphogenesis was able to be achieved under controlled illumination, when compared with the conventional intermittent illumination, 12L12D (12 hours light and 12 hours darkness), or continuous lighting.
\end{abstract}

Keywords : bio-electric potential, biorhythm, light control, Grifola frondosa, morphogenetic properties

緒言

近年, 低カロリーでリグニンや $\beta$-グルカンなどの機能性成 分を含み食物繊維が豊富な茸類は, 健康食品として注目され

2007 年 9 月 21 日受付

2008 年 2 月 12 日受理

Corresponding author : Junji Hirama

(kit83013@neptune.kanazawa-it. ac.jp)
需要が拡大し, 咠工場での人工栽培が普及している. 従前 から人工栽培での栽培環境条件は, 現場の生産者の経験に より確立されてきたが, 科学的な根拠の裏付けが遅れている. これまでに我々は, マイ夕ケ, エリンギ, ナメコなどの茸の栽培 現場での聞き取り調査に基づいた環境条件を踏まえ, 子実体 の生体電位を計測し生長促進に作用する至適生育条件を科 学的に検討してきた.

その結果, 子実体の生体電位が大きく誘発される光刺激 を連続的に与えると, 子実体の発達が促進されることや, 連 
続的な光照射に比べて断続的な照射を与えると, さらに子実 体の発達が促進することから, 生体電位変動と生長とは密接 に関わっていることを明らかにしてきた ${ }^{1,2)}$. そして, 連続的な 光照射であっても生体電位には自発性の概周期的なりズム変 動が存在すること ${ }^{3)}$ などを明らかにしてきた. さらに, マイタケ の子実体では, 30 分間隔の点滅光で生体電位が顕著に誘 発することを踏まえ, 30 分や 15 分間隔の点滅光で形態形成 の比較も行った，その結果，生体電位の変化が最も顕著な 15 分間隔照射では菌傘が良く展開する形態形成を示した.

本研究では上記の研究成果に基づき, 特にマイ夕ケの自発 性生体電位に含まれる概周期性の生体リズム変動特性に着 目し，茸工場における生産性の向上を目指す新たな光源制 御方法を提案する. すなわち, マイ夕ケをバイオセンサとして

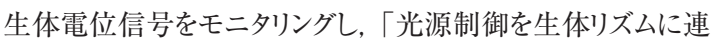
動させたマイタケ栽培技術」を試みた。

\section{実験方法}

\section{1.形態形成および生体電位計測装置}

Fig. 1 は, 過去に我々が試作した種々の光の波長や強度 を提示できる形態形成実験装置 ${ }^{1,2)}$ に新たに光源制御装置 を組み込んだ実験システムを示す, 本装置はチャンバ (容量
約 36 l)を 7 個備えており, 各チャンバにてマイタケ (Grifola frondosa (Dicks. Fr). S. F. Gray) を栽培した. いずれのチヤ ンバ内も空気組成は, 温度 $18^{\circ} \mathrm{C}$, 湿度 $90 \% \mathrm{RH}$, 酸素濃度 $21 \%$, 二酸化炭素濃度 $500 \sim 800 \mathrm{ppm}$ 一定とし, PC でチャ ンバ内の空気循環を均一に制御した.

原基形成後 5 日目のマイ夕ケ菌床を供試体とし, 14 日間栽 培して最終日の形態形成の比較をした. なお, 栽培期間中に はそれぞれの子実体上部に誘導電極として塩化銀膜を生成 した約 $\phi 0.5 \mathrm{~mm}$ の正極の銀針電極を挿入し, 負極をその下 部約 $1 \mathrm{~cm}$ の部位に, 不関電極をマイタケ子実体と菌床との 境目に，それぞれ深さ約 $1 \mathrm{~cm}$ で挿入した，そして，雑音対策 を十分施した ( 分解能は約 $10 \mu \mathrm{V}$ 以下) 自作の生体電位ア ンプ (CMRR: $120 \mathrm{~dB}$ 以上, $\mathrm{S} / \mathrm{N}$ 比約 $80 \mathrm{~dB}$ )を介して, 誘 発した生体電位の変化を PCにて 1 分間毎に記録した. 実 験回数はのべ 3 回とした. また, 光源には我々がこれまでに 子実体の生長が良好であることと生体電位が大になることを 報告 ${ }^{1)}$ している自作の青色 $\operatorname{LED}(\lambda \mathrm{p}=468 \mathrm{~nm})$ パネルを用 いた. な押, マイタケ菌傘上部とパ亲ルとの距離は常時 $3 \mathrm{~cm}$ とし, 光の強さは $6 \mathrm{Wm}^{-2}$ 一定とした. また, 実験終了後, 新 鮮重の比較も行った.

\section{2.生体電位のリズム変動に連動した光源制御}

過去に我々はマイ夕ケ子実体上部に, 青色光を光の強さ 6

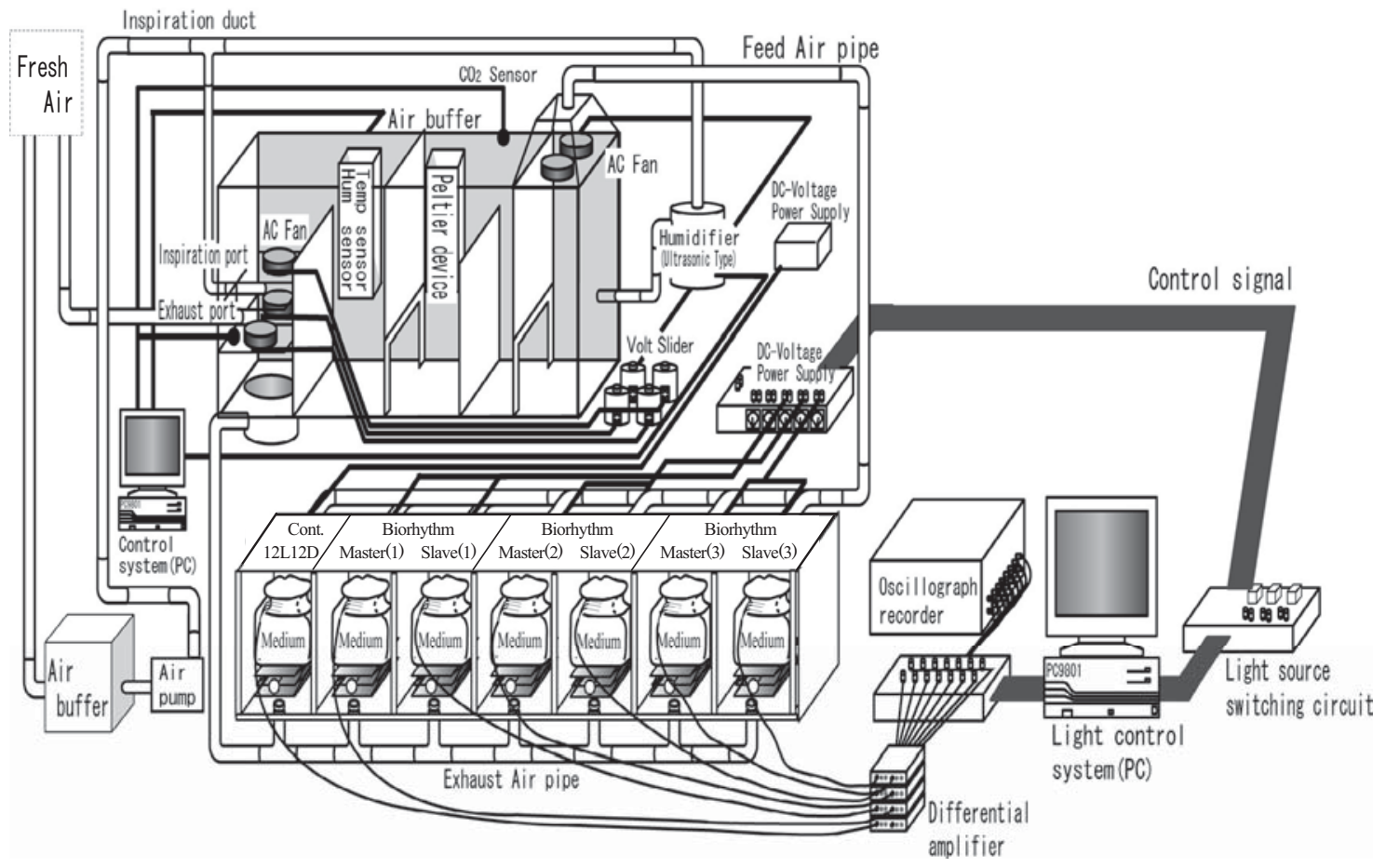

図 1 形態形成実験装置システム

Fig. 1 Experimental system for observing growth. 


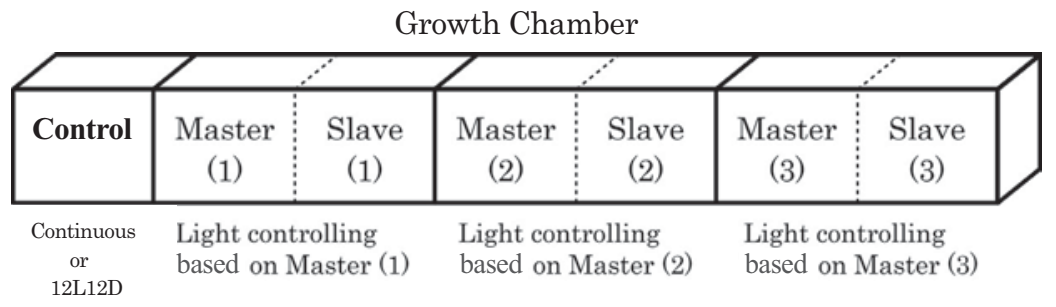

図 2 生体電位信号と光源制御との関係

Fig. 2 Itemization of the chambers.

$\mathrm{Wm}^{-2}$ で長期間に渡り連続照射した場合の生体電位変動を 観測した. その結果, 概周期的な生体リズム連動を伴いなが ら生体電位が変化することを明らかにした ${ }^{3)}$. また, 生体電位 変動が大となる光刺激を提示することで, 菌傘の展開が発達 したり，新鮮重が増加するなどを明らかにしてきた ${ }^{1,2)}$. また， 自然界の様々な物理現象や生物の生体生理特性などに多く 観測される $1 / \mathrm{f}$ ゆらぎ ${ }^{4)}$ を付加した光刺激を与えることや, 数 時間 (約 10 時間) 周期や短時間 (数 10 分) 周期の間欠 的な光照射により, 子実体の生体電位を強制的に誘発させる ことで生長が促進する結果も得ている. このように光刺激の 提示条件が形態形成に及ぼすことがわかっている ${ }^{5)}$.

そこで, 今回は新たな試みとして咠の生体リズムを伴った自 発性生体電位信号に連動させて, 光刺激の点灯制御を行う ことで, 形態形成へ及ぼす影響を検討した ${ }^{6}$.

Fig. 2 は, Fig. 1 に示した光源制御部分における生体電 位信号と光源制御との関係を示す. 子実体の生体電位変 化をモニ夕し, 自発性の生体電位のリズムに連動させて光 源を制御する個体側をマス夕と定義した. 一方, マス夕の電 位変動に連動して強制的に光照射の ON/OFFをさせる 個体側をスレーブと定義した. 本研究では特定の 1 個体の マイタケをバイオセンサとして生体電位のリズム変動を計測し, これに基づき咠工場全体の咠の光源を制御するシステムの 構築を目標にしている. 今回はマスタとスレーブの 3 個のペア を試験区とし, 12L12D (12 h 毎の照射・非照射)の間欠照 射あるいは連続照射を対照区とした. なお, 今回はこの両者 の対比を行うことで, 間欠照射の方が連続照射に比べて新 鮮重が大となった, 過去の予備結果も検証することを試みた.

\section{3.光源制御のアルゴリズム}

Fig. 3 は光源制御のフローチャートの概要を示す. 1 分毎 に PCに記録された生体電位データより, 現時点から過去の 60 個分 (1 時間相当) を特定の分析区間長として, その区 間デー夕の回帰直線を求め, 生体電位の傾きを計算した. そ の傾きをあらかじめ設定した閾值と比較し, 閾值を越えてかつ 傾きが正ならば照射, 一方, 傾きが負ならば非照射となるよう に光源を制御した. Fig. 4 は具体的な光源制御の概念図を
示す. 横軸は経過時間, 縦第 1 軸は生体電位, 縦第 2 軸は 生体電位の傾きを示す. 同図 (a) の場合, 計測開始から 60 分後には計 60 個の生体電位デー夕が取得され, 回帰直線に よる傾きの算出が可能な状態になる (同図中 A 点). その後 1 分経過毎に, 過去 60 分間の分析区間長の生体電位の傾 きを算出し, 以降これを繰り返す. そして, 生体電位の傾きが 任意に設定した正の閾值を下回る期間は, 光源は非照射の 状態を維持し, 一方, 上回った瞬間 (同 B 点) に照射の状 態に切り替えられる. その後, 例えば同図 (b) に示すように, 生体リズムが下降して生体電位の傾きが負の閾值を超えた場 合 (同 C 点) には, 光源は照射の状態から非照射の状態に 切り替えられる. なお, 実験開始から最初の 60 分間は傾きが 求まらないので非照射の状態を維持するように設定した.

\section{4.閾値の設定}

光源装置の $\mathrm{ON} / \mathrm{OFF}$ の閾值を試行的に $3.6 \mathrm{mVh}^{-1}, 2.4$ $\mathrm{mVh}^{-1}, 1.2 \mathrm{mVh}^{-1}, 0.6 \mathrm{mVh}^{-1}$ の 4 種類に設定し, 閾値より 生体電位の傾きが大の時には光源を $\mathrm{ON}$, 小の時には $\mathrm{OFF}$ となるように制御 (この時には便宜的に閾值の前に+/ーの 記号を付記 ) した. また, 予備的に閾值が $1.2 \mathrm{mVh}^{-1}$ と 0.6 $\mathrm{mVh}^{-1}$ の 2 種類のみ, 光源の $\mathrm{ON} / \mathrm{OFF}$ の制御を逆 (閾值

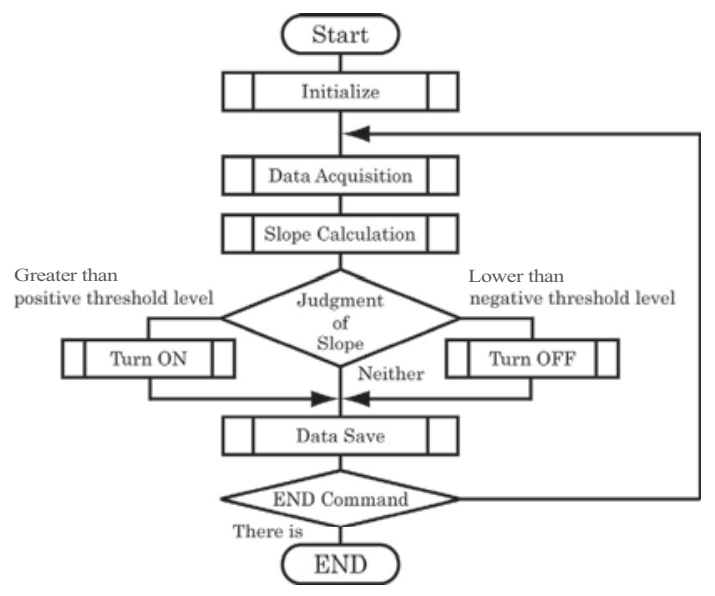

図 3 光源制御のフローチャート

Fig. 3 Flow chart of light control. 


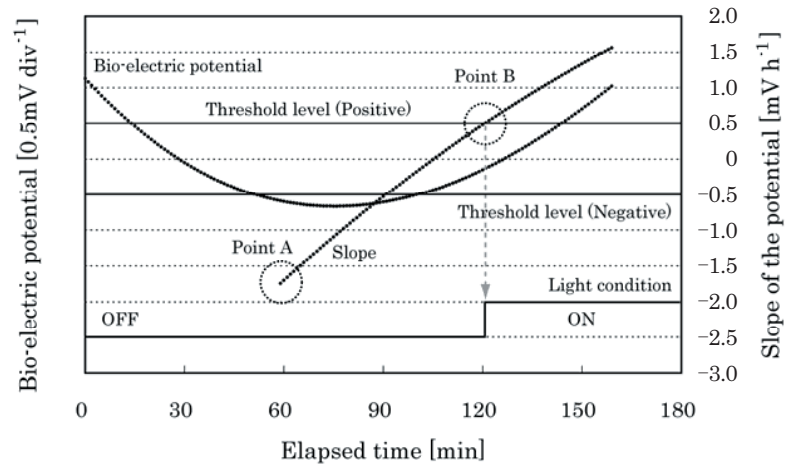

(a) Changes from non-irradiation to irradiation.

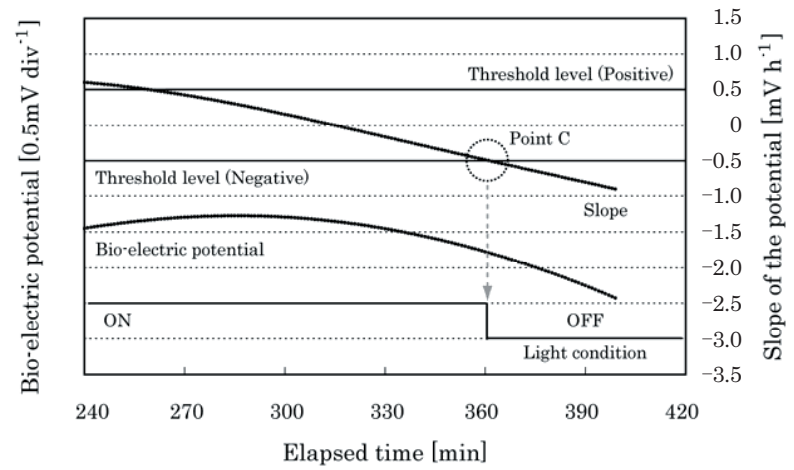

(b) Changes from irradiation to non-irradiation.

図 4 光源制御の概念図

Fig. 4 A schematic diagram of light control.

の前にー/+の記号を付記 ) として形態形成の比較も行った.

\section{結果および考察}

\section{1.形態形成の比較}

Fig. 5 は実験の最終日 (14 日目) の代表的な生育結果を 示す. 上段に側面，下段に上面からの様子を示す. 同図 (a) から (c) は LED パネルの ON/FF の閾值が $3.6 \mathrm{mVh}^{-1}$ から $0.6 \mathrm{mVh}^{-1}$ まで変化させ, いずれも生体電位の上昇で光源 を ONとしたマス夕側, 一方, (d) から (f) は, (a) から (c) の 条件下でのスレーブ側を示す. また, $(\mathrm{g})$ と (h) は閾值が 0.6 $\mathrm{mVh}^{-1}$ において, 生体電位下降で光源 $\mathrm{ON}$ となる場合のマ スタ側とスレーブ側を示す。これらの結果より以下のことがわ かる.

閾值+ /-3.6 mVh ${ }^{-1}$ から+/-0.6 $\mathrm{mVh}^{-1}$ では, 閾值が小さ くなるほど菌傘が展開し発達した形態となった. (a) + / - 3.6 $\mathrm{mVh}^{-1}$ の場合は菌傘が未発達で樹状の形態となった. マス 夕側とスレーブ側との形態形成を比較すると, わずかではあ
るがスレーブ側の菌傘が発達した形態となる傾向が観測され た. さらに同一の閾值であっても生体電位下降で光源 ONと なる逆の光源制御の場合でも, 同図 $(\mathrm{g})$ と $(\mathrm{h})$ に示すように 菌众が大きく展開した形態となった. なお, 同様な実験をのべ 3 回行った結果, いずれもほぼ同様な結果を示した.

ところで, 生体電位の生体リズム変動に連動させない場合 の青色 LED 光を用いた形態形成の代表的な実験結果を Fig. 6 に示す. 同図 (a) は暗黒化, (b) は連続照射, (c) は 12L12D を示す.

図示のように暗黒下では生育不十分で, いわゆる樹状の 形態となり, 連続および 12L12D では子実体の発達が見られ る形態を示している. さらに 12L12D においては, Fig. 5 で示 した $1.2 〜 0.6 \mathrm{mVh}^{-1}$ と比べても, ほぼ同様な形態形成とな つた.

\section{2. 新鮮重の比較}

Fig. 7 は, 各光制御における試験区の新鮮重の比較を示 す. 条件毎に 3 個体の平均值を示し, 各閾值の左側にマス 夕側, 右側にスレーブ側の結果を示す. また, 対照区として連 
続照射と 12L12D の結果も示した. 閾値+ / - 3.6 + / - 0.6 $\mathrm{mVh}^{-1}$ を比較すると, 閾值の值が小さくなるほど新鮮重が大 きいことがわかる. なお，連続照射と 12L12D との比較では, 過去の結果と同様に ${ }^{21} 12 \mathrm{~L} 12 \mathrm{D}$ の方が新鮮重が大きくなる傾 向を示した. また, これらの䦨值においてマス夕側とスレーブ 側とを比較すると, すべての閾值でスレーブ側では新鮮重が 大となっていることがわかる. この理由については今後検討す る予定であるが, 特定の個体をバイオセンサとして他の個体 の生育をコントロールすることが可能であることがわかった.さ らに子実体の発達が見られた 2 つの閾值+ / -1.2 と+ / -0.6
$\mathrm{mVh}^{-1}$ において, 光照射タイミングが逆となる光源制御を試 みた結果, $-/+1.2 \mathrm{mV} / \mathrm{h}$ の場合では+ / $-1.2 \mathrm{mVh}^{-1}$ よりも 新鮮重が大きくなった. しかし, $-/+0.6 \mathrm{mVh}^{-1}$ の場合では + /-0.6 $\mathrm{mVh}^{-1}$ に比べて新鮮重が若干小さくなった. - / +や +/一のように, 生体電位の上昇や下降に対応した光源の照 射や非照射と形態形成との関係には一貫性がないが,これま でに茸の生育促進作用をもたらす技術として, 光や温度など の外的刺激により子実体内部の生体電位を強制的に変動さ せて生育の活性化を図ることが有効であることを明らかとして いる ${ }^{1,2)}$. このことから類推し, 今回のように生体電位の上昇

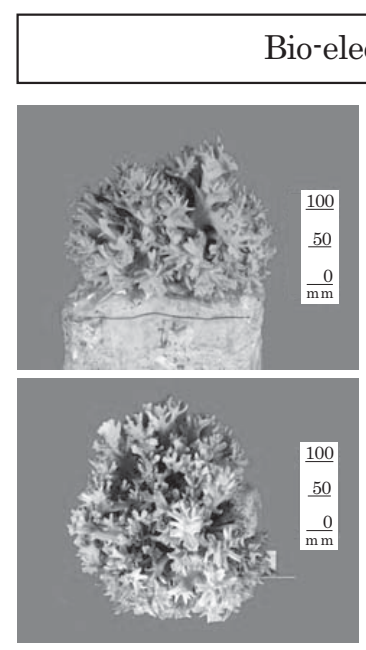

(a) $+/-3.6 \mathrm{mVh}^{-1}$

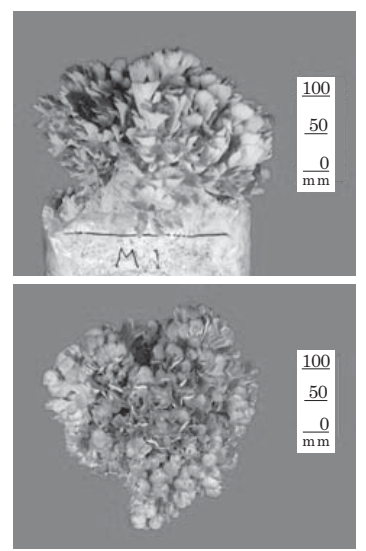

(b) $+/-1.2 \mathrm{mVh}^{-1}$

Master
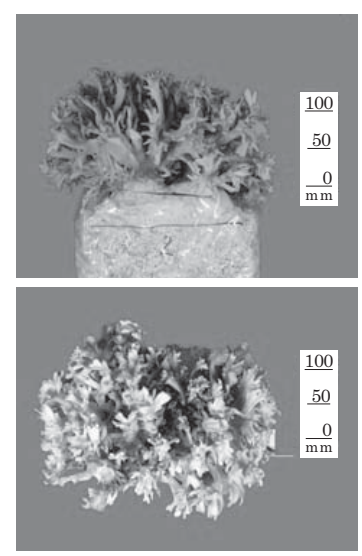

(d) $+/-3.6 \mathrm{mVh}^{-1}$
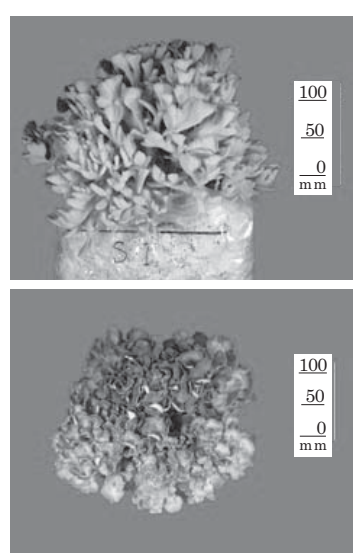

(e) $+/-1.2 \mathrm{mVh}^{-1}$

Slave

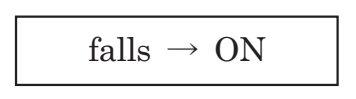

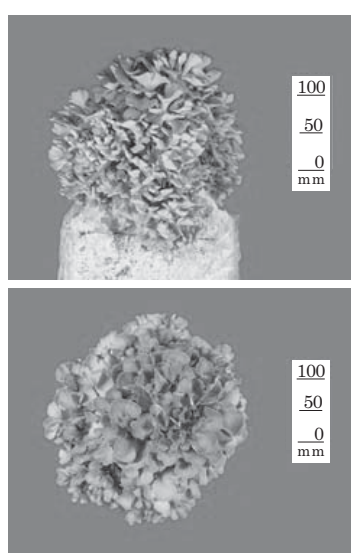

(c) $+/-0.6 \mathrm{mVh}^{-1}$
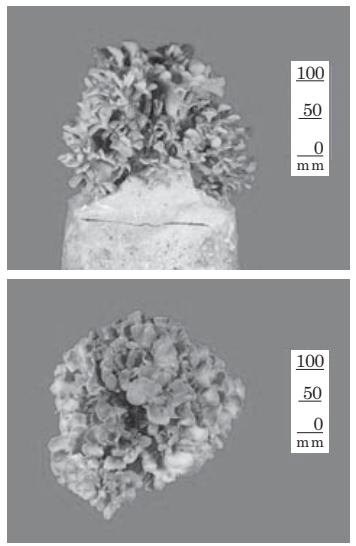

(f) $+/-0.6 \mathrm{mVh}^{-1}$

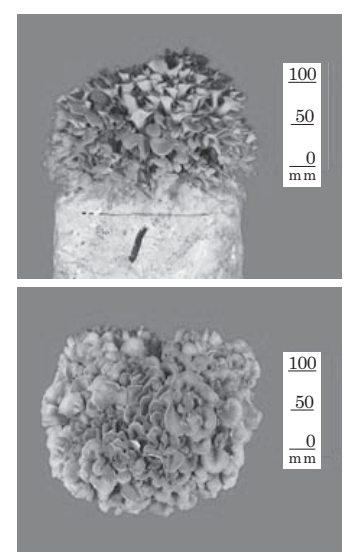

(g) $-/+0.6 \mathrm{mVh}^{-1}$

Master
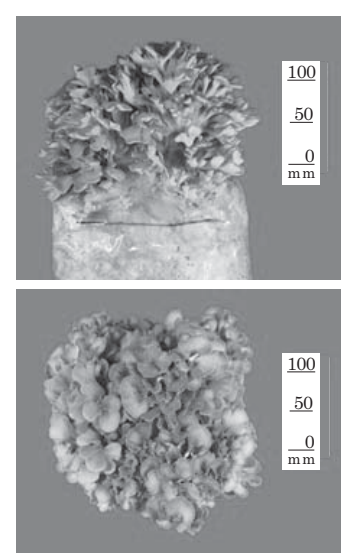

(h) $-/+0.6 \mathrm{mVh}^{-1}$

Slave

図 5 光源制御方法を変えた形態形成実験結果

Fig. 5 Typical morphogenetic properties under different light control. 

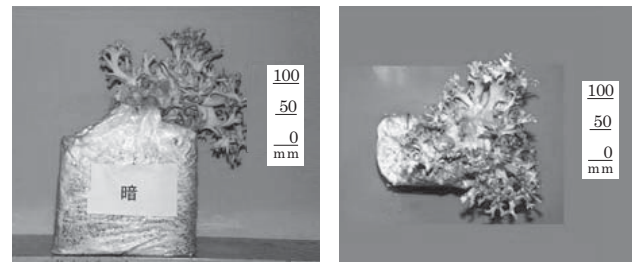

(a) Continuous dark condition (dentritic shape).
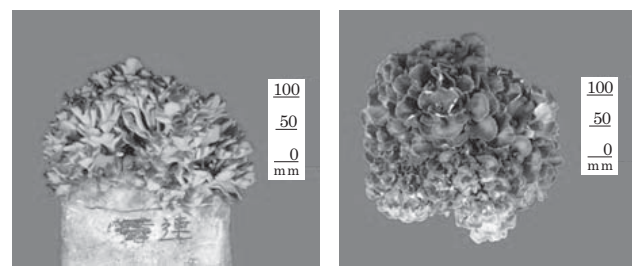

(b) Continuous irradiation.
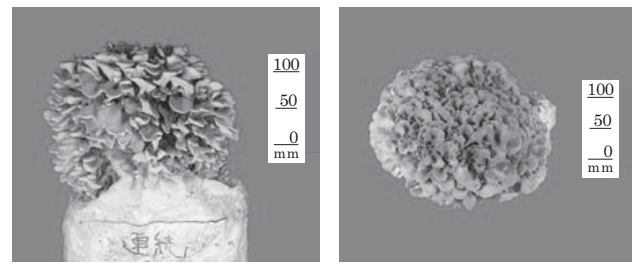

(c) $12 \mathrm{~L} 12 \mathrm{D}$.

図 6 生体リズム制御なしでの形態形成の比較

Fig. 6 Comparison of the morphogenesis without the biorhythm control.
/下降の区別に限定しなくても, 単にリズム変動に連動した光 照射や非照射を提示することで, 子実体の発達を促す形態 形成を呈したと考えられる.

また, +/-1.2 $\mathrm{mVh}^{-1}$ のスレーブ側, + / $-0.6 \mathrm{mVh}^{-1}$ と -/ + $1.2 \mathrm{mVh}^{-1}$ および-/ + $0.6 \mathrm{mVh}^{-1}$ のマス夕側とスレーブ 側の 7 種類の光刺激では新鮮重が約 $1000 \mathrm{~g}$ となり, 連続照 射より重量が重く12L12D の場合とほぼ類似した.この結果 は, 茸生育期間における総照射時間と関連すると考えられ, 詳細は以下の 3. で述べる.

\section{3.光刺激タイミングと閾值の関係}

Fig. 8 は実験期間 14 日間の生体電位変化とその傾き, お よび LED 点灯状況を示す. 同図 (a) は Fig. 5 で示したよう に樹状の形態となった闇值 $+/-3.6 \mathrm{mVh}^{-1}$, 同図 (b) は形態 形成拉よび新鮮重ともに良好であった閾值+ $/-1.2 \mathrm{mVh}^{-1}$ で 栽培した結果を示す.これらの結果から以下のことがわかる.

同図 (a)に示すように, +/-3.6 $\mathrm{mVh}^{-1}$ では生体電位の傾 きが閾值に達せず, 長時間光源 ON 及び OFF 状態を保持 している. ところで, これまで実施してきた約 350 個体のマイ 夕ケ子実体では, 実験後半の栽培 7 日目以降から生体電位 変動は観測されるものの, 変動が小さくなる傾向が確認され ている. このような特性を踏まえると, 8 日目 (192 時間) 以降 では, 傾きの閾值を大きく設定すると, 今回の生体リズム制御 では閾值に達することができず, 光源制御が不適切であるこ とが推定できる. これに対し, 同図 (b) に示す+ $/-1.2 \mathrm{mVh}^{-1}$ の小さな閾値の設定では, 生体電位の傾きは実験期間中に は閾值に達しており, 生体電位変動が小さくなる実験後半で あっても光源制御が行われていたと推定できる.

また, Fig. 8 に示した実験期間中における,のべ 336 時

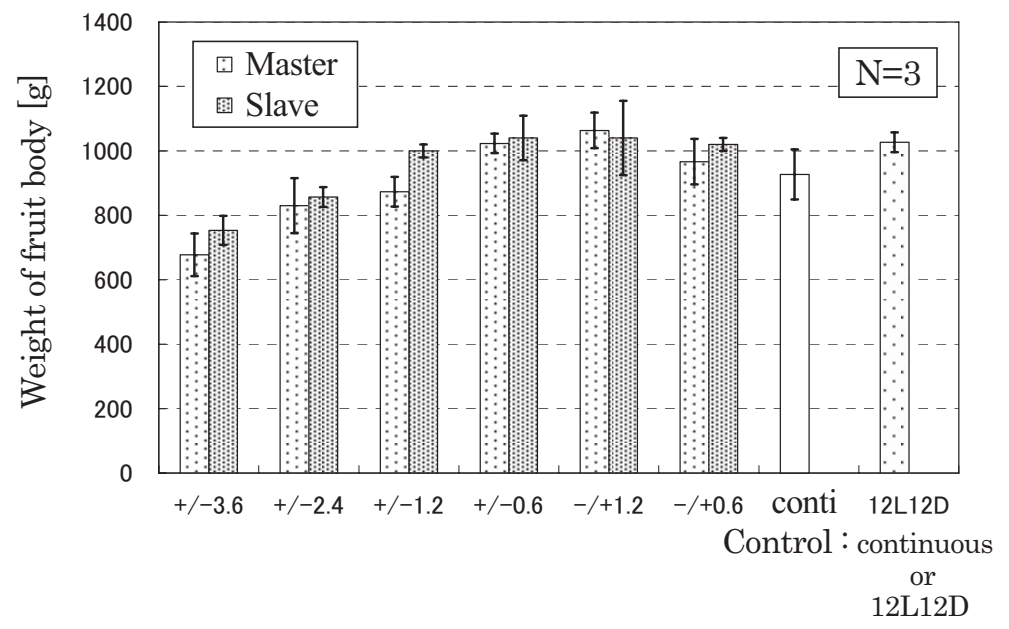

図 7 光刺激の間值ごとの新鮮重の比較

Fig. 7 Relationship between various threshold levels and the weight of fruit body. (Bars indicate : mean \pm SD) 
間 (14 日間 )のうち, 光照射された総時間を求めると, (a)+ /-3.6 mVh ${ }^{-1}$ では光の照射は約 94 時間であり, これは実験 期間中の照射比率に換算すると全体の約 $28 \%$ に相当する. このことから暗状態で栽培した場合に観察される, いわゆる 光量不足に起因する「樹状の形態」5)になったと推定でき る.

一方, (b) $+/-1.2 \mathrm{mVh}^{-1}$ では実験期間中のうち, 光の照 射は約 165 時間となり, 約 $50 \%$ の照射比率に相当する. この 比率は 12L12D と同一となる. Fig. 7 に示した新鮮重の比較 結果では, ほぼ同様な重量であるが, Fig. 5 の (b) と (e) と Fig. 6 の (c) に示した形態を比較すると, 生体リズム制御の 方が 12L12D に比べて菌傘の展開が発達する傾向を示して いる. 生産者からの聞き取り調査によれば, マイタケは菌傘が
良く展開し, かつ新鮮重の増大が見込まれる方が市場ニーズ が高いと伺っている. したがって, 今回提案した生体リズム連 動制御による栽培技術は, 12L12D に比べて菌傘の発達を促 し, 新鮮重はわずかながらも増加する傾向が見込まれ, 本技 術の有効性が示唆された.

今後は, より効果的な生長促進をもたらすような光強度や 閾值などの設定条件などについても, 更に検討を予定してい る. なお, 本研究では, 子実体の生体電位変動に着目した 光源照射に対するバイオリズム制御が形態形成へ及ぼす影 響のみに言及している. しかし, 生産性の観点からは「色づ き」や「味覚」などのカテゴリの定量評価も重要と考えてい るので, 今後検討する予定でもある.

ところで, 生体リズムに連動させた制御は, 自然界や物理

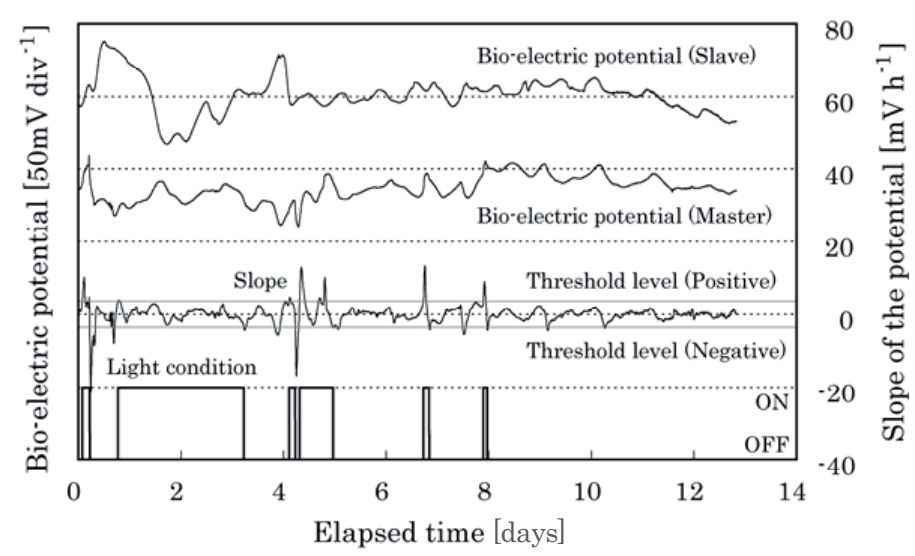

(a) Case of $+/-3.6 \mathrm{mV} \mathrm{h}^{-1}$

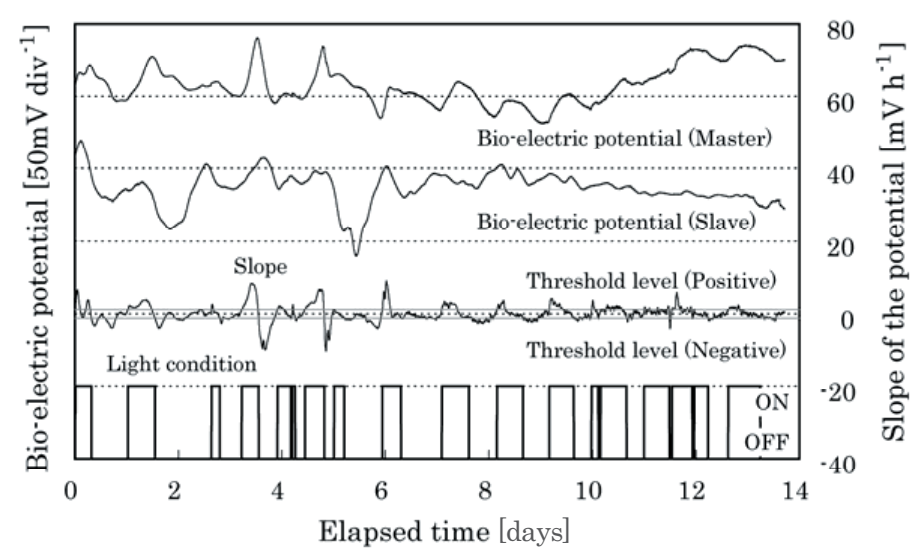

(b) Case of $+/-1.2 \mathrm{mV} \mathrm{h}^{-1}$

図 8 生体電位変化と光源制御

Fig. 8 Changes in bio-electric potential and light control. 
現象でもしばしば観測される「引き込み現象」7)に類似した 作用を及ぼし, 生長促進をもたらしたと考えられる. しかし, 今回の実験結果と「引き込み現象」との関係については, 現在は不明なので今後検討する予定である.

\section{摘 要}

本研究ではマイタケ子実体の生体電位信号をモニタリング し, 信号中の概周期的な生体リズム成分より, 光照射の夕イミ ングを制御する方法を考案した. すなわち, 子実体をバイオセ ンサとして用いることで, 生体電位の自発性リズム変動に連動 させた光照射を用いる新たな栽培技術を提案した. 約 1 時 間分析区間長毎の生体電位の上昇や下降の変動特性に応 じて, 光源装置の点灯あるいは消灯タイミングを試行的に設 定した. その結果, 12L12D (12 時間 Light, 12 時間 Dark) の間欠照射あるいは連続照射に比べて, 生体電位のリズム 変動に連動させた光源制御の方が菌傘の展開が発達した り, 新鮮重が増加する傾向となり, 咠工場内での生産性向上 が見达まれる結果を得た。このように, 本研究では特定の個 体をバイオセンサとして生体電位信号のリズム変動を計測し て, その信号に連動させて咠工場全体の光源を制御するシ ステムの基盤が構築できたと考えている.

なお, 本研究成果の一部は文部科学省科学研究費 ( 基 盤研究 (C) : 課題番号 16560420) の助成による.

\section{引用文献}

1) 平間淳司, 柳橋秀幸, 松田真人, 石田 良, 宮本紀男. 光刺激による舞咠の子実体の生体電位反応と形態形 成との関係. 電気学会論文誌 122-C(9)：1679-1685. 2002.

2) 柳橋秀幸, 平間淳司, 松田真人, 宮本紀男. 生体電位 を指標としたマイタケの至適生育温度の探求および生 長促進の試み. 125-E(4) : 159-164. 2005.

3) 柳橋秀幸, 松田真人, 平間淳司, 宮本紀男, 西堀耕三, 大平安夫. 光刺激による咠 (マイタケ) の生体電位反 応 (第 4 報) 一子実体および培地内部のリズム変動特 性一. 植物工場学会誌 16(4) : 193-197. 2004.

4) 武者利光, 沢田康次. ゆらぎ・カオス・フラクタル. 日本 評論社, 東京, 59-110. 1991.

5) Hirama J.. Relationship between the bio-electric potential and the morphgenetic properties of Grifora frondosa when subjected to different light stimuli. In: Proc. First Japan-Thailand Symposium on Advanced Technologies in Agricultual Production and PostProduction Operations. Thailand. 8-9 December, 89-94. 2003.

6) 松岡大輔, 柳橋秀幸, 平間淳司, 宮本紀男, 西堀耕三, 大平安夫. 光源制御を生体リズムに連動させたマイタケ 栽培技術の提案. In : 農業環境工学関連 7 学会 2006 年合同大会, 講演要旨集 CD. 札幌. 9 月 11 日 -15 日. 2006.

7) 吉川研一. 非線形科学一分子集合体のリズムとかた ち一. 学会出版センター, 東京, 12-22. 1992 